\title{
Impact of Climate Change on Kinnow Fruit Industry of Pakistan
}

\author{
Rab Nawaz ${ }^{1}$, Nadeem Akhtar Abbasi ${ }^{1 *}$, Ishfaq Ahmad Hafiz ${ }^{1}$, Azeem Khalid ${ }^{2}$, Touqeer Ahmad ${ }^{1}$ and \\ Muhammad Aftab ${ }^{1}$
}

${ }^{1}$ Department of Horticulture, Pir Mehr Ali Shah Arid Agriculture University, Rawalpindi, Pakistan; ${ }^{2}$ Department of Environmental Sciences, Pir Mehr Ali Shah Arid Agriculture University, Rawalpindi, Pakistan

\begin{abstract}
Citrus fruits are prominent crop of tropical and sub-tropical region which require suitable climate for quality production. Kinnow mandarin is dominant cultivated in the plain of the Punjab, Pakistan. Being a perennial crop, citrus is more vulnerable to changing environmental conditions and both physical and biochemical quality parameters are deteriorated by erratic behavior of weather around the year. The present study was conducted to assess the impact of climate change on citrus industry of Pakistan and selected three main citrus groves of the Punjab province. The selected orchards were uniform in age, vigor and planting geometry by using factorial (RCBD) while survey design was performed to assess impact of climate change on Kinnow fruit industry. Climate change has triggered pest's infestation, disease incidence and water use and ultimately increased inputs cost. Heat and drought stress and fog was more observed in Vehari and Toba Tek Singh (TTS) and more yield reduction and low quality was recorded in these districts than Sargodha. Processing cost increased and more export risk was seen with market fluctuation in climate change scenario. Increased in input cost, water requirement of plant, reduction in net return and uncertain market were observed. Climate change has directly affected citrus industry and scientific approach requires addressing these challenges.
\end{abstract}

Keywords: Kinnow fruit; Climate change impact; Input cost; Net return; Kinnow yield

\section{INTRODUCTION}

Citrus ranks dominant position among fruits in area and production in Pakistan and Kinnow mandarin (Citrus nobilis Lour X Citrus deliciosa Tenora) is widely grown in province of the Punjab [1]. Punjab is leading in citrus growing area where Kinnow is dominantly cultivated (91\%) [2].

Pakistan has touched highest export volume of Kinnow fresh fruit (370 thousand tons) and value (US\$ 222 million) during the season 2017-2018 [3] due to favorable environmental conditions and bumper crop at home and less export hurdles faced at external level [4]. In last three year, more fruit quality deteriorated due to uneven weather conditions and high competition with world in citrus fruit exporting market [5]. Our export is hardly $10-12 \%$ of country total production and rest is consumed domestically [6]. Climate change and erratic behavior of weather round the year restricted quality production of Kinnow fruit in Pakistan while in global market more preference is given to cosmetic outlook of fruit and internal quality that is main reason of our less export, especially in high returning markets of European Union where our export just fetch 2\% [7]. Citrus fruit quality linked with critical phenological growth stages where orchard management, irrigation and pests-disease control can enhance it, but any change in prevailing environmental conditions negatively affect fruit physicochemical quality.

Abiotic and biotic factors intermingled with climate change that may influence fruit quality and yield and directly income of the orchard [8]. The ongoing trend of climate change has increased means temperature, altered rainfall patterns and frequency and climatic variability became extreme [9] that has substantially altered agricultural systems and crop preference [10]. Mitigation strategies of various natures were adopted to minimize its adverse effects [11] but perennial crops like orchard received less research focus except Valencia orange yields in the Southern United States [12] and vine grape yield and quality in wine-growing regions [13]. Citrus being a perennial fruit that long-lived and may change slowly than annual crops and has become more vulnerable to climate change [14].

Initial works were done on effect of biotic (pests and diseases) and abiotic (environmental factors and orchard management) stresses

Correspondence to: Nadeem Akhtar Abbasi, Department of Horticulture, Pir Mehr Ali Shah- Arid Agriculture University, Rawalpindi, Pakistan, Tel: +92-51-9290914; E-mail: nadeemabbasi65@yahoo.com

Received: November 20, 2019, Accepted: February 11, 2019, Published: February 20, 2019

Citation: Nawaz R, Abbasi NA, Hafiz IA, Khalid A, Ahmad T, Aftab M (2019) Impact of Climate Change on Kinnow Fruit Industry of Pakistan. Agrotechnology 8:186. doi: 10.35248/2168-9881.19.8.186

Copyright: ( $) 2019$ Nawaz R, et al. This is an open-access article distributed under the terms of the Creative Commons Attribution License, which permits unrestricted use, distribution, and reproduction in any medium, provided the original author and source are credited. 
on citrus fruit [7], but influence of climate change on fruit quality and its risk and economic perspective requires more research which is needed to be focused on priority basis.

Citrus yield and quality is hinged on climatic factors in the subtropical region $[15,16]$ and temperature has direct relation with Growing Degree-Days (GDD) or heat units that determines fruit development and fruit maturation [17] while any extreme event during fruit growth phases may have direct effects on yield and quality. Previous research indicated that climatic factors like temperature, precipitation, wind, solar radiation, fog and frost have direct effects on Kinnow fruit quality and yield and any change in these factors adversely affected production. Therefore growing of this crop in certain areas would be at risk. In this context, present study was conducted in the main citrus groves of the Punjab province three districts namely Sargodha, Toba Tek Singh (TTS) and Vehari and assessed the impact of climate change on the citrus industry of Pakistan and economically analyzed its adverse effects.

\section{MATERIALS AND METHODS}

The present study on impact of climate change in Citrus (Kinnow fruit) industry was conducted in the year (2017-2018) in three main citrus growing districts of the Punjab province, Pakistan namely Sargodha $\left(32.0837^{\circ} \mathrm{N}, 72.6719^{\circ} \mathrm{E}\right)$ altitude $189 \mathrm{~m}$, Toba Tek Singh $\left(30.9727^{\circ} \mathrm{N}, 72.4850^{\circ} \mathrm{E}\right)$ altitude $161 \mathrm{~m}$ and Vehari $\left(30.0452^{\circ} \mathrm{N}\right.$, $72.3489^{\circ} \mathrm{E}$ ) altitude $140 \mathrm{~m}$.

\section{Weather data}

The average annual rainfall from 2000 to 2018 was recorded higher in Sargodha $(410 \mathrm{~mm})$, followed by TTS $(255 \mathrm{~mm})$ and minimum in Vehari $(169 \mathrm{~mm}$ ) while annual average temperature was found higher in Vehari $\left(26.5^{\circ} \mathrm{C}\right)$, followed by TTS $\left(24.8^{\circ} \mathrm{C}\right)$ and minimum in Sargodha $\left(22.9^{\circ} \mathrm{C}\right)$. Monthly rainfall and temperature given below.

\section{Selection of orchards}

The selected orchards were uniform in age, vigor and plant geometry and selected plants were tagged to record data. Twigs of pencil size of each plant at three canopy positions (lower, middle and upper) and within canopy (outer, middle and inner sides) and plant four directions (north, south, east and west) were tagged to record fruit data.

\section{Data collection}

Monthly basis data of fruit on tagged branches were taken and incidence of diseases on fruits, pests damaged fruits and drop on monthly basis was collected. Fruit drop during heat stress, drought stress and smog/fog period were calculated to evaluate yield reduction and economic loss.

\section{Yield reduction}

On monthly basis fruit drop percentage was collected and during heat and drought stresses and smog period, drop fruit percentage was used to calculate yield reduction.

\section{Impact on fruit quality}

Abiotic and biotic stresses like wind scares, pests damaged and diseases incidence were counted from tagged branches. Fruit yield and quality (fruit grades) were calculated at harvesting. Increased pests and diseases damaged and abiotic stresses were noted during erratic weather behaviour.

\section{Survey design of farmers}

A survey was conducted of farmers to assess their perception on fruit quality in past and present and impact of climate change and their inputs increased. Fruit grades and rejection at farm gate was calculated from farmers' survey. Present quality was recorded in field and past perceived from survey. Similarly farmers input on cultural practices, plant protection (pesticides and fungicides) and water irrigation at present was noted and increased was perceived through survey. Farmers income and input at present were compared through their past.

\section{Survey design of market and processing units}

A survey of markets was performed to assess grades prices and market gluts and fluctuation at present and past and compared difference in climate change. Similar survey of processing units and exporters were performed to assess their perception on fruit quality, input increased and export risk at present and what was in past and compared both to assess climate change impact.

\section{Statistical design}

A factorial (RCBD) was used with three replications and three plants per replication in field. Data regarding parameters was compared by using LSD test with 5\% significance level. Means data was collected from three individual plants during season 2017 and 2018 for every replication at the end of each month's whole the period of two years. Five farmers in one cluster and three clusters in each district were selected for data collection. Three major markets in each district were chosen for data collection regarding fruit quality, grades rate, fluctuation and duration of fresh fruits in present and past and difference was calculated. Similarly, fifteen processing units/exporters survey was performed. Three groups were made and five included in each group regarding climate impact on fruit quality, export risk, processing cost, domestic market. Present status was compared with past record.

\section{RESULTS AND DISCUSSION}

Data analysis showed significant impact of climate change in Citrus industry of Pakistan, which was explained and discussed under.

\section{Inputs increase}

Among different inputs, maximum increase in cultural practices and fungicide application were noticed in district Sargodha (10\% and $9 \%)$ followed by TTS $(9.33 \%$ and $9 \%)$ and minimum increase in input cost was in district Vehari (9\% and 6\%). As far as overall pesticide applications and water requirement is concerned, maximum increased was observed in Vehari $(10 \%$ and $11 \%)$ followed by TSS ( $8 \%$ each) and Sargodha (6.33 and 5\%). Keeping all this input increase under consideration, overall input was recorded in Vehari (36\%) followed by TTS (33.33) and Sargodha $(30.33 \%)$ as shown in Figure 1. 


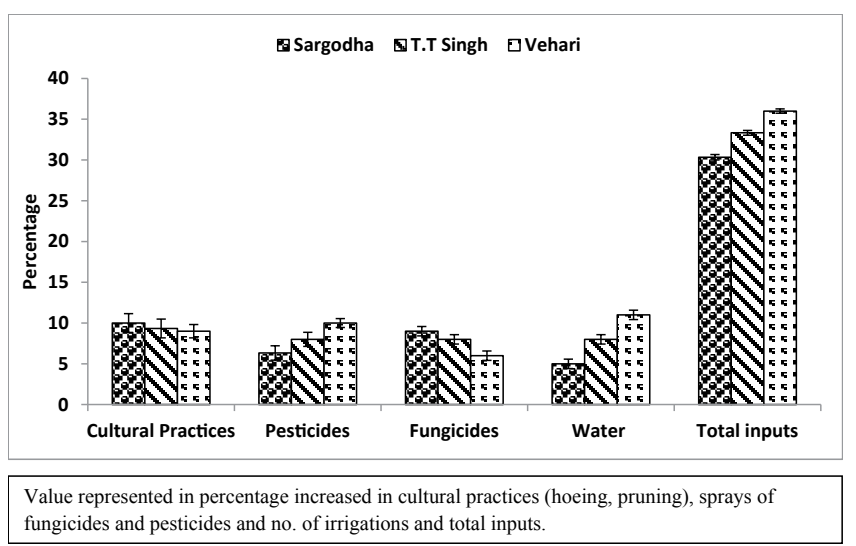

Figure 1: Inputs increase in climate change scenario.

Climate change has increased input cost and more cultural practices like pruning, hoeing and other operations needed to produce quality fruit because shift in hydrological cycle [18], resulting in extreme of dry versus wet conditions [19] that has disturbed whole ecosystem in which more pests infestation and disease incidence occurred and altered ecological processes, including species interactions [20]. In dry extreme more pests infestation and water requirement have been observed in Vehari while wet condition promoted disease incident as was seen in Sargodha. In both case more inputs incurred on pesticides and fungicides in Vehari and Sargodha respectively while prolonged dry spell or less rainfall in Vehari and TTS has increased water demand of the citrus orchard. Climate change has alter photosynthetic rate, shift growth rate, overall productivity and resource use [21,22] and ultimately more inputs needed.

\section{Fruit drop percentage}

Different causes of fruit drop percentage were observed in three different districts of Punjab, presented in Figure 2. Maximum increase in fruit drop due to heat stress, drought stress and smog was observed in Vehari $(6.17 \%, 3.5 \%$ and $10 \%$ respectively) followed by TTS $(4.16 \%, 2.5 \%$ and $9 \%$ respectively) and Sargodha (3.67,2 and $7 \%$ respectively). Overall maximum increase in fruit drop was noticed in Vehari (19.67\%) followed by TTS (15.67\%) and Sargodha (12.67\%).

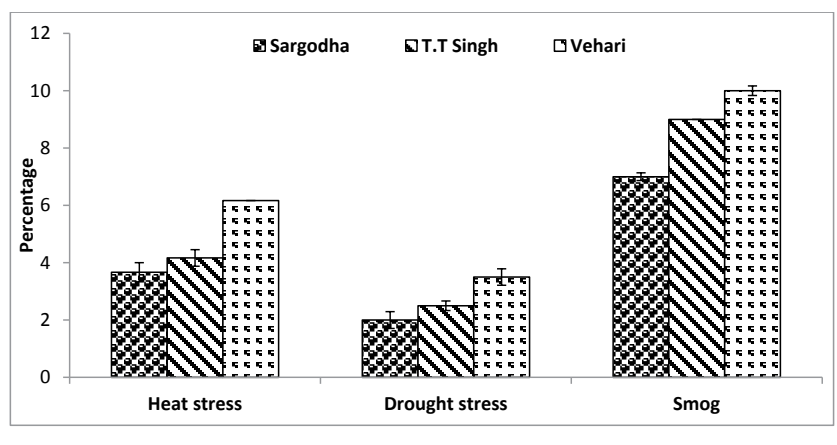

Value in percentage calculates from fruit drop on tagged branches more during heat stress, drought stress and smog.

Figure 2: Fruit drop percentage increase in changing climate.

Climate change has altered rainfall pattern and raised temperature. Citrus fruit exposed to heat stress in April and May when fruit are just small in size. This stress resulted in physiological fruit drop [15]. More fruit drop was observed in Vehari due to heat and drought stress. Rise in temperature caused more physiological drop in citrus plant [23] and water scarcity due to drought also caused premature fruit drop in June [24] as was seen in Vehari and TTS where high temperature and less rainfall resulted in more fruit drop percentage as compared with Sargodha. Recent phenomena of smog due to dust particles pollution [25] has posed serious threat for plant and injured tissues and denatured chloroplast that decreased pigments in leaves [26] and ultimately less carbon assimilation resulted in less photosynthesis [27]. Inhibition of plant growth activities can alter biochemical change [28] and resulted in fruit drop. Smog was more observed in Vehari and TTS than Sargodha and consequently more mature fruit drop recorded in these districts.

\section{Impact on yield, quality and market}

Data regarding yield reduction, quality, deterioration and market fluctuation showed significant difference among different districts of Punjab as shown in Figure 3. Maximum yield reduction and quality deterioration was observed in Vehari (13\% and 7\%) followed by TTS (12\% and 6\%) and minimum in Sargodha (10\% and $4 \%$ ) while market fluctuation was observed maximum in Sargodha (11\%) followed by Vehari (7\%) and minimum in TTS (6\%).

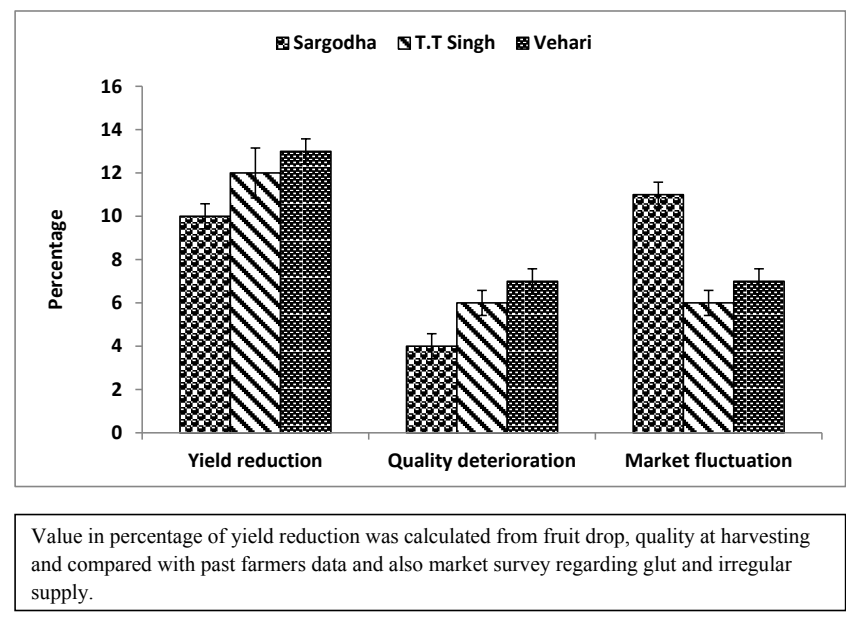

Figure 3: Impact on yield, quality and market in climate change.

Inconsistent weather and change in climate [29] has reduced yield of citrus crop while market demands more quality with less chemical use. More adverse effect of climate change observed in Vehari and TTS and more yield reduction and quality deterioration was recorded in these districts. Heat and drought stress and smog high intensity was seen in Vehari and TTS which resulted in more fruit drop so in these districts more reduction in yield and quality deterioration was noted as compared to Sargodha while more glut in market and price fluctuation was observed in Sargodha due to squeeze period of fruit on tree and less exportable fruit. More uneven temperature was observed in Sargodha which resulted in fruit yield reduction and quality deterioration. In Sargodha fruit bearing period reduced and harvesting was completed up to February which created glut in market and price fluctuation more than Vehari and TTS.

\section{Fruit quality assessment}

Varying environmental conditions put substantial impact on fruit quality which is presented in Figure 4. Maximum A grade fruit was harvested from district Sargodha (12\%) followed by TTS (9\%) which was at par with Vehari (9\%) while B grade fruit was maximum TTS (44.33\%) followed by Vehari (43.33\%) and Sargodha (37.67\%). 
Moreover $\mathrm{C}$ grade was observed maximum in district Sargodha (40\%) followed by Vehari (37.67\%) and TTS (34.33\%). Rejection at farm gate was found statistically non-significant.

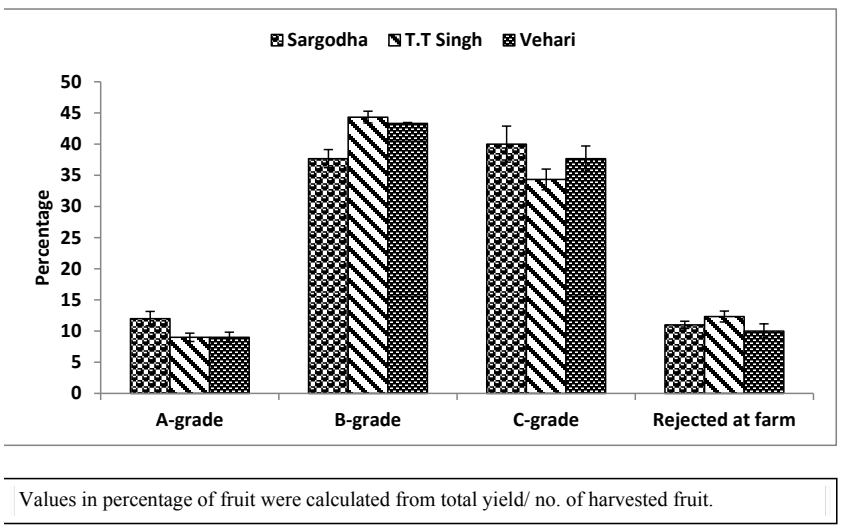

Figure 4: Fruit quality under climate change scenario.

Fruit quality directly linked with price and as more good quality more price and vice versa [30]. Cosmetic outlook and fruit firmness are considered attributes to determine fruit grading for postharvest process [31]. Fruit quality is directly link with prevailing environmental conditions that may vary from location to location. High temperature in ripening stage may cause softening of skin and high wind velocity at fruit pea size damaged cosmetic outlook of fruit [32]. In Sargodha pests' pressure was low and fruit skin damaged by thrips and mites observed less than Vehari and TTS and more A grade fruits were recorded. While diseases like scab and melanose was comparatively higher in Sargodha but not too much while wind scaring on fruit remain same in all three districts. B-grade fruit was more in TTS and Vehari than Sargodha while C grade recoded higher in Sargodha due to more humid condition and incident of scab on fruit. Rejected at farm site fruit was recorded at same level in all three districts damaged by fruit fly and citrus red scale. Fruit fly damaged was more observed in Vehari and TTS due high temperature in November which favour oviposition while humid condition favour red scale infestation on fruit in Sargodha. Both pests deteriorated fruit quality and climate change favors their outbreak [33].

\section{Impact on fruit quality}

Reduction in different quality grades were observed in three districts and presented in Figure 5. Maximum reduction in A and B grade fruit were observed in District Vehari (-8\% and $-13 \%)$ followed by TTS $(-7 \%$ and $-12.5 \%)$ and minimum in Sargodha $(-6 \%$ and $-11 \%)$, while $\mathrm{C}$ grade and farm rejection was maximum in Sargodha (5\% and 6\%) followed by TTS (3.33\% and 4\%) and Vehari (3\% and $4 \%$ ).

Climate change more vulnerability was observed in districts Vehari and TTS than Sargodha and more reduction in A and B grade fruit was recoded in these districts. Sunburn, heat stress and rise of temperature in April has damaged citrus fruit more in Vehari and TTS than Sargodha and more quality deterioration was seen $[34,35]$. Wind damages fruit peel/skin through abrasion and was more observed in Sargodha. Fruit A-grade fruit was more noted in Sargodha than Vehari and TTS. Humid condition in Sargodha resulted more citrus scab and melanose diseases and red scale infestation that led to more C-grade fruit production and fruit rejection at farm gate/orchard site and more secondary pests invasion seen [36].

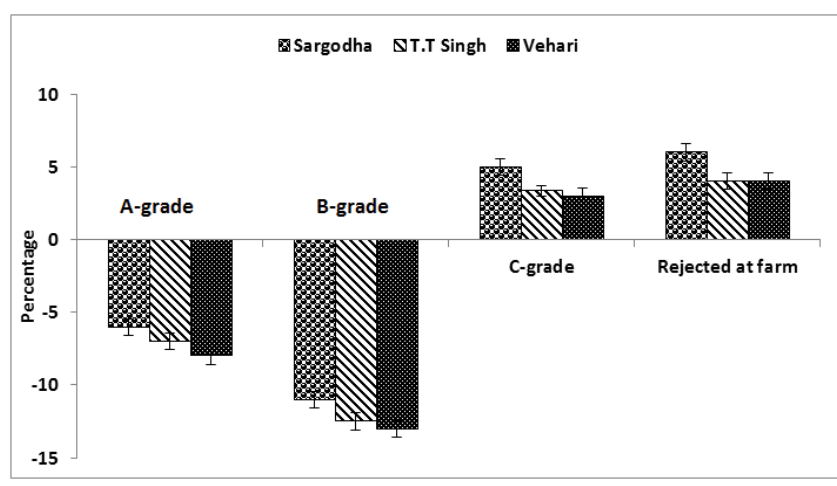

Values in percentgaes were calculated from actual yield at farm and compared with past data.

Figure 5: Climate change adverse effects on fruit quality.

\section{Impact on fruit price}

Revenue collected from different grades of Kinnow mandarin was studied in different districts and presented in Figure 6. Maximum revenue from A grade and C grade was obtained in Sargodha (31.93\% and $21.29 \%$ ) followed by TTS (26.49\% and $16.42 \%)$ and Vehari $(24.78 \%$ and $15.56 \%$ ), while revenue generated from B grade was maximum in Vehari (59.66\%) followed by TTS $(57.09 \%)$ and Sargodha (46.78\%).

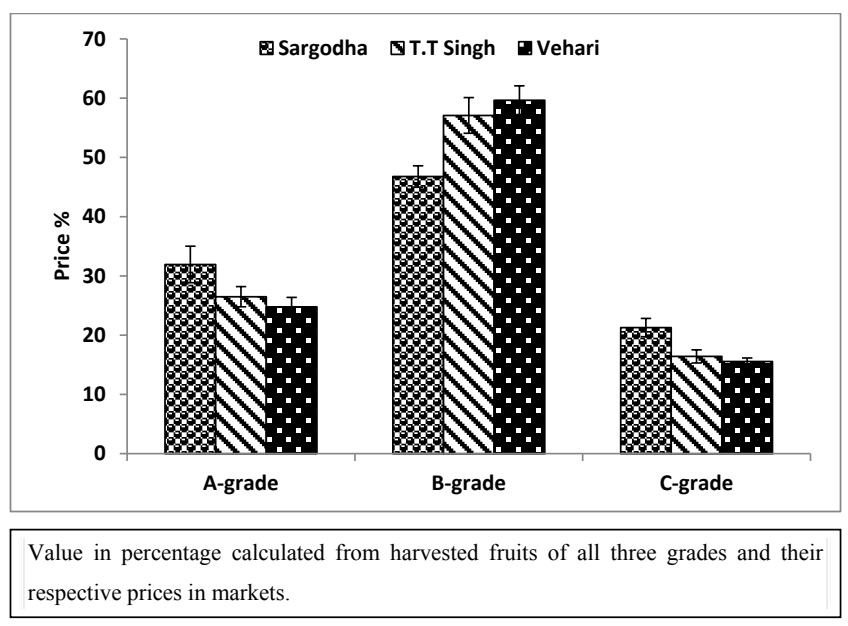

Figure 6: Climate change adverse effects on fruit price.

The value of perennial crops like citrus is not derived from quantity but also quality of actual harvest [37] and climate change further complicated perennial crop quality production and exact response of climate change is highly uncertain [38,39]. In district Vehari and TTS, less A grade fruit produced and low price fetched by quality of fruit while B grade was more in production and same case is with revenue generation. Sudden rise temperature in June in Sargodha has reduced cell division resulting in small size of fruit [40] and more $\mathrm{C}$ grade was recorded and more revenue come from $\mathrm{C}$ grade fruit in this district. High temperature has caused more fruit skin damaging pests and deteriorated quality and market values. In Vehari and TTS, Kinnow fruit quality is not up to standard level. Only district Sargodha citrus is exported due to quality and more price come from A grade. 


\section{Impact on processing cost, export and domestic market}

Impact of current climatic situations on processing cost, export and domestic market were evaluated and presented in Figure 7. Among processing maximum cost increase was observed in storage (12\%) followed by grading (9.33) and labor (6.67\%). Among export risks, increase in quality issues were observed maximum (6.33\%) followed by sanitation (6\%) and MRLs issue (4\%). As far as domestic market is concerned, significant decrease in availability duration was noticed (12\%) and increase in fruit deterioration was recorded maximum (11.33\%) followed by market glut (10.67\%).

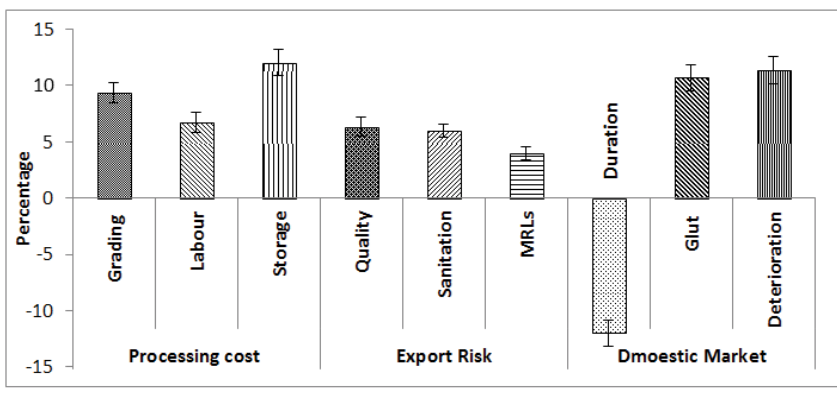

Value in percentage increases/decreases were calculated from present data compared with past in survey design.

Figure 7: Climate change effect on processing cost, export risk and domestic market.

Global warming has hastened 38\% harvesting period [41] and more time required for storage to sell fruit stable market and more glut observed in market. Citrus industry contributed to GDPs and generated more employment opportunities [42]. Climate change resulted in wide spread of disease and pests which reduced citrus yield and deteriorated fruit quality and economically damaged citrus industry [43]. Processing cost due grading of inferior fruit, fruit fly cold treatment and labor cost increased while export risk also become high. Fruit quality deteriorated due to more climatic variability and more pesticides and fungicides application was recorded and more sanitation and MRLs faced by citrus industry in exporting fruit. Rise in temperature resulted earlier maturity and more glut in domestic market and fruit was harvest in short duration. In market, citrus fruit duration squeezed, more glut and deterioration was increased.

\section{Economic perspective}

Different climatic conditions put significant impact on cost and benefit scenario of Kinnow mandarin orchard as presented in Figure 7. Maximum increase in inputs and crop water requirement was observed in district Vehari $(16.33 \%$ and $16 \%$ respectively) followed by TTS (14.67\% and $11 \%$ respectively) and minimum in Sargodha (13.67\% and 7\% respectively). Decrease in net return was minimum in Sargodha (12\%) followed by Vehari (14\%) and maximum in TTS (15.33\%), while increase in market uncertainty was witnessed maximum in district Sargodha (16\%), followed by TTS (12\%) and minimum in Vehari (11\%).

Citrus industry in climate change scenario come under potential threat of diseases and pests which led to reduction in yield and economic losses while input cost increased [44]. In climate change scenario, hydrological cycle is more affected [45] and global warming increased crop water requirement [46]. Citrus net return remains low in erratic behavior of weather which directly affected yield and quality of fruit [47]. In Pakistan, climate change has adverse effect on citrus industry and marketing [48]. Inputs increased in Vehari and TTS due to pests pressure and more plant protection measures were required and due to less rainfall and high temperature, more irrigation needed in Vehari than rest of other districts while net return remained less in climate change but marginally slight different among districts. Market uncertainty was more seen in Sargodha due to diseases incidence like scab and melanose outbreak and glut in market while less uncertain in Vehari and TTS as their fruits not exported and consumed in domestic market (Figure 8).

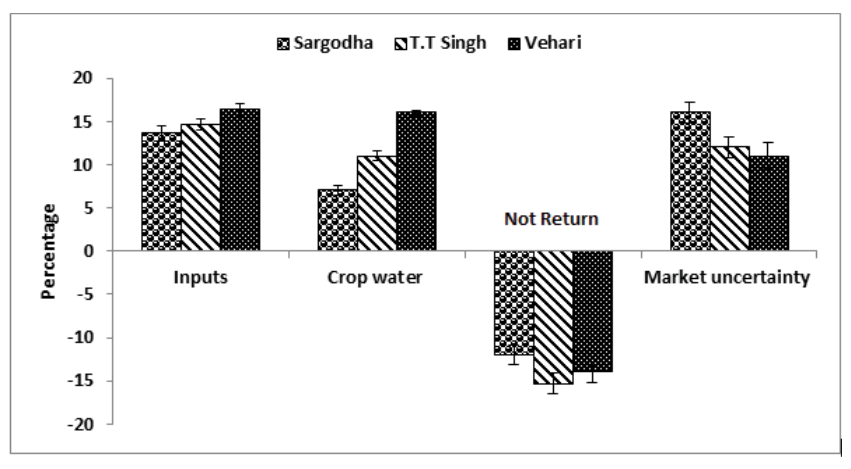

Values in percentage were calculated from net return at present and parameter compared present with past data of field experiment and survey design.

Figure 8: Economic perspectives under changing climate.

\section{CONCLUSION}

Climate change has adversely affected Kinnow fruit in Pakistan. Yield reduction with inferior quality and more fluctuation in market has added woes to Kinnow industry and disturbed supply chain mechanism with less return from orchards. Increased heat waves with low rainfall in starting period of summer and more temperature with prolonged humid condition during autumn have adversely affected Kinnow mandarin. Extreme climatic variability varies from location to location has affected plant physiology, built up more pests pressure, favoured diseases incidence and finally affected both producers and consumers. The present study will be used in future to define risk of citrus fruit in certain areas and future challenges of industry in climate change scenario.

\section{ACKNOWLEDGEMENT}

HEC Pakistan for providing Indigenous Fellowship (2AV3-109) and Agriculture Department, Government of the Punjab granting study leaves for $\mathrm{PhD}$.

\section{References}

1. Ghafoor U, Muhammad S, Ch KM. Constrains in availability of inputs and information to citrus (Kinnow) growers of tehsil Toba Tek Singh, Pakistan. J Agric Sci. 2008;45:520-522.

2. Statistical Bureau of Pakistan (Provincial Crops Reporting Service) Islamabad. 2017.

3. Trade Development Authority of Pakistan Report, Islamabad. 2018.

4. Pakistan Horticulture Development \& Export Company Islamabad. 2018. 
5. Pakistan Horticulture Development \& Export Company Islamabad. 2017.

6. Trade Development Authority of Pakistan Report, Islamabad. 2017.

7. Ahmed M. Nature and extent of fruit blemishes in Kinnow mandarin. University of Agriculture Faisalabad, Pakistan. 2005.

8. Ullah R, Shivakoti GP, Ali G. Factors effecting farmers' risk attitude and risk perceptions: The case of Khyber Pakhtunkhwa, Pakistan. IJDRR. 2015;13:151-157.

9. Intergovernmental Panel on Climate Change (IPCC). Climate Change 2007: The Physical Science Basis. Contributions of Working Group I to the Fourth Assessment Report of the Intergovernmental Panel on Climate Change. Cambridge and New York: Cambridge University Press. 2007.

10. Parry ML, Rosenzweig C, Iglesias A, Livermore M, Fischer G. Effects of climate change on global food production under SRES emissions and socio-economic scenarios. Glob Environ Change. 2004;14:53-67.

11. Burton I, Lim B. Achieving adequate adaptation in agriculture. Clim Change. 2005;70:191-200.

12.Tubiello FN, Rosenzweig C, Goldberg RA, Jagtapand S, Jones JW. Effects of climate change on US crop production: simulation results using two different GCM scenarios. Part I: Wheat, potato, maize, and citrus. Clim Res. 2002;20:259-270.

13. White MA, Diffenbaugh NS, Jones GV, Pal JS, Giorgi F. Extreme heat reduces and shifts United States premium wine production in the $21^{\text {st }}$ century. Proc Natl Acad Sci. 2006;103:11217-11222.

14.Jones GV, White MA, Cooper OR, Storchmann K. Climate change and global wine quality. Clim Change. 2005;73:319-343.

15. Davies FS, Albrigo LG. Citrus crop production science in Agriculture. CAB International: Wallingford. 1994;pp:1-8.

16. Makinde AA, Afolayan SO, Olaniyan AA, Odeleye OMO, Okafor BN. Effect of climate on citrus yield in rainforest-savanna transitional zone of Nigeria. J Agric Bio Sci. 2011;2:010-013.

17. Reuther W. Climate and citrus behavior: 280-337. In: W Reuther editor. The Citrus Industry. University of California Press. Berkeley, USA. 1973.

18. IPCC Climate change 2013: The physical science basis. Contribution of working group I to the fifth assessment report of the Intergovernmental Panel on Climate Change. Cambridge, United Kingdom and New York, USA: Cambridge University Press. 2013.

19. Medvigy D, Beaulieu C. Trends in daily solar radiation and precipitation coefficients of variation since 1984. J CLI. 2012;25:1330-1339.

20.Shefferson RP, Salguero-Gómez R. Eco-evolutionary dynamics in plants: interactive processes at overlapping time-scales and their implications. J Ecol. 2015;103:789-797.

21. Norby RJZ, Donald R. Ecological lessons from free-air $\mathrm{CO}_{2}$ enrichment (FACE) experiments. Annu Rev Ecol Evol Syst. 2011;42:181-203.

22. Medeiros JS, Ward JK. Increasing atmospheric $\left[\mathrm{CO}_{2}\right]$ from glacial to future concentrations affects drought tolerance via impacts on leaves, xylem and their integrated function. New Phytol. 2013;199:738-748.

23. Bhatnagar P, Jain MC, Singh J. Physiological fruit drop in ambe bahar of Nagpur mandarin (citrus reticulata blanco.). IJEST. 2016;5:28852890.

24. Albrigo LG, Syvertsen JP. Status of citrus fruit drop in relation to HLB. Citrus Industry J. 2015;pp:14-17.

25.Grantz DA, Garner JHB, Jhonson DW. Ecological effects of particular matter. Environ Int. 2003;29:213-239.

26.Krishna JR. Effect of coal dust pollution on the vegetation around Dhanbad Coalfield. Bio Journal. 1999;11:59-61.
27. Singh P, Sthapak J. Reduction in Protein contents in few plants as indicators of air pollution. Pollut Res. 1999;18:281-283.

28. Borka G. Effect of cement kiln dust on Maize plant. Acta Agron Hung. 1981;30:289-295.

29.Shahak Y. Photoselective netting: an overview of the concept, $R \& R$ and practical implementation in agriculture. Acta Hort. 2012;1015:155-162.

30.Mahajan BVC, Dhatt AS, Rattan GS. Evaluation of various wax formulations on the post-harvest characteristics of kinnow. Indian J Citricult. 2002;1:185-188.

31. Maude L, Bouageois G. Effect of preharvest weather conditions on firmness of McIntosh apples at harvest time. Hort Sci. 2013;48:474-480.

32.Chikaizumi S. Studies on causal factors and preventive measures of rind disorders in citrus fruits. Memoirs of the Faculty of AgricultureEhime University (Japan). Citrus Industry J. 2007;pp:14-15.

33.Lee TC, Zhong PJ, Chang PT. The effects of preharvest shading and postharvest storage temperatures on the quality of 'Ponkan' (Citrus reticulate Blanco) mandarin fruits. Scientia Horticulturae. 2015;188:5765.

34.Ladaniya MS. 17-Physiological disorders and their management. Citrus Fruit. 2008a;pp:451-463.

35.Ladaniya MS. 19-Fruit quality control, evaluation, and analysis. Citrus Fruit. 2008b;pp:475-499.

36.Singha H, Al-Samarraia G, Syarhabila M, Yin-Chua S. Minimizing postharvest damage in citrus. International Conference on Chemical and Bioprocess Engineering, Andra Pradesh, India 125. 2015.

37. Glena DM, Kim SH, Villegas JR, Laderich P. Response of perennial horticultural crops to climate change. Horticultural Reviews, First Edition. 2013;41.

38. Meehl GA, Stocker TF, Collins WD, Friedlingstein P, Gaye AT, Gregory JM, et al. Global climate projections. In: Climate change 2007: The physical science basis. Contribution of Working Group I to the Fourth Assessment Report of the Intergovernmental Panel on climate change. Cambridge Univ. Press, Cambridge and New York. 2007.

39. Hawkins E, Sutton R. The potential to narrow uncertainty in regional climate predictions. Bull Am Meteorol Soc. 2009;90:1095-1107.

40.Caprio JM, Quamme HA. Weather conditions associated with apple production in the Okanagan Valley of British Columbia. Can J Plant Sci. 1999;79:129-137.

41. Sugiura T. What become of 'Agriculture' and 'Food' by Global Warming? Gijyutuhyoronsya, Tokyo, Japan. 2009.

42.Hodges A, Rahmani M, Stevens T, Spreen T. Economic Impacts of the Florida Citrus Industry in 2012-13. University of Florida, Gainesville, FL, 2014;pp:1-34.

43. Hodges AW, Spreen TH. Economic Impacts of Citrus Greening (HLB) in Florida, 2006/7-2010/11. Food and Resource Economics Department, Institute of Food and Agricultural Sciences, University of Florida, Gainesville, FL. 2006;pp:1-6.

44.Gottwald TR, Graham JH, Schubert TS. Citrus canker: the pathogen and its impact. Plant Health Prog. 2002.

45.Agarwal A, Babel MS, Maskey S. Analysis of future precipitation in the Koshi river basin Nepal. J Hydrol. 2014;513:422-434.

46. Hassan Z, Shamsudin S, Harun S. Application of SDSM and LARSWG for simulating and downscaling of rainfall and temperature. Theor Appl Climatol. 2014;116:243-257.

47.Zekri M. Factors affecting citrus production and quality, Citrus industry. 2011.

48.Shahzad A, Iram F, Ghulam HJ, Mehar UNR, Abdul QM. Economic impact of climate change on the production of citrus fruit in punjab province of the pakistan. Sci Int. 2017;29:413-415. 